\title{
JEKK
}

Jurnal Epidemiologi Kesehatan Komunitas

$2(2), 2017,54-61$

\section{Faktor Risiko yang Berpengaruh terhadap Terjadinya Hipertensi pada Penderita Diabetes Melitus Tipe II di Wilayah Puskesmas Kabupaten Pati}

\author{
Gracilaria Puspa Sari", Shofa Chasani ${ }^{* *}$, Tjokorda Gde Dalem Pemayun ${ }^{* *}$, Suharyo Hadisaputro ***, \\ Heri Nugroho ${ }^{* * * *}$ \\ *Puskesmas Pati I, ${ }^{* *}$ RSUP Dr. Kariadi Semarang, ${ }^{* * *}$ Politeknik Kesehatan Semarang, ${ }^{* * * *}$ Fakultas \\ Kedokteran Undip
}

\begin{abstract}
Background : The prevalence of hypertension in type 2 diabetic patients is 1,5-3 times higher than it is in nondiabetic individuals This chronic condition accelerates macrovascular complications. Research about risk factors of hypertension in type 2 diabetic patients is still rare because its causes multifactorial. The objectives of this research is to explain the risk factors affecting hypertension in type 2 diabetic patients.

Methods : An observational studies with case-control study design in Primary Healthcare Centers patients in Pati District. Patients with hypertension in type 2 diabetes are the case, while the type 2 diabetes patients without hypertension are the control. There were 57 cases and 57 controls included. Data were obtained from medical records and qualitative interviews. Chi-square test in bivariate and multiple logistic regression in multivariate analysis.

Results : Factors that influence hypertension in type 2 diabetic patients were physical activity $(\mathrm{OR}=6,4 ; 95 \% \mathrm{CI}: 2,18-18,77 ; \mathrm{p}=0,001)$, diabetes duration $\geq 5$ years $(\mathrm{OR}=5,4 ; 95 \%$ CI: 1,97 - 14,704; $p=0,001)$, and medication adherence $(\mathrm{OR}=3,6 ; 95 \%$ CI: $1,32-9,83$; $\mathrm{p}=0,012$ ). Other risk factors i.e age $\geq 45$ years, male, diet compliance, history of hypertension, smoking, salt consumption, coffee consumption, and sleep duration were not significantly influenced.
\end{abstract}

Conclusion : In this study, physical activity, diabetes duration, and DM medication adherence are risk factors that influence of hypertension in type 2 diabetic patients.

Keywords: Type 2 diabetes mellitus; hypertension;risk factors

Penulis korespondensi : rex_ndet@yahoo.com 


\section{Pendahuluan}

Diabetes melitus (DM) merupakan suatu penyakit kronik yang ditandai dengan adanya hiperglikemi sebagai akibat berkurangnya produksi insulin, ataupun gangguan aktivitas dari insulin ataupun keduanya. ${ }^{1}$ DM yang tidak dikelola dengan baik dapat mengakibatkan komplikasi vaskuler, salah satunya adalah hipertensi. ${ }^{2}$ Penderita DM tipe 2 sering mempunyai tekanan darah lebih tinggi atau sama dengan 150/90 mmHg. ${ }^{3}$ Hipertensi pada penderita DM tipe 2 dapat menimbulkan percepatan komplikasi mikrovaskuler maupun makrovaskuler. ${ }^{4}$

Studi menunjukkan mortalitas kardiovaskuler 2-3 kali lebih tinggi pada penderita diabetes hipertensi dibanding diabetes normotensi. ${ }^{5}$ Studi lain menyatakan pasien DM tipe 2 dengan hipertensi memiliki risiko 7 kali lebih besar untuk mengalami gagal ginjal terminal (ESRD) ${ }^{6}$ dan 2-4 kali terjadi penyakit kardiovaskular, seperti infark miokard, stroke, atau kematian, dibandingkan dengan pasien DM tipe 2 normotensi pada usia yang sama. ${ }^{7}$

Menurut WHO, jumlah penderita DM di dunia tahun 2013 mencapai 381,8 juta orang, diperkirakan menjadi 591,9 juta pada tahun $2035 .^{8}$ Beberapa studi epidemiologi menunjukkan prevalensi hipertensi pada pasien dengan DM adalah 1,5-2 kali lebih besar daripada populasi non DM. ${ }^{9}$

Hasil penelitian menunjukkan bahwa 2.688 studi observasional tentang prevalensi hipertensi pada pasien DM tipe 2 di seluruh dunia, 50-75\% kasus hipertensi muncul menyertai DM tipe $2 .{ }^{10}$ Indonesia menempati peringkat ketujuh di dunia dengan jumlah penderita diabetes 8,5 juta orang pada tahun $2013 .^{8}$ Data Riskesdas 2013 menunjukkan prevalensi diabetes di Indonesia sebesar $1,5 \%$, sedangkan di Jawa Tengah memiliki prevalensi diabetes melebihi angka nasional yaitu sebesar 1,6\% .
Prevalensi hipertensi di Indonesia yang didapat melalui pengukuran pada umur $\geq 18$ tahun sebesar $25,8 \%$, dengan prevalensi hipertensi di Jawa Tengah sebesar 26,4\%. ${ }^{11}$ Besarnya kasus hipertensi pada DM tipe 2 di Indonesia dan Jawa Tengah sampai saat ini belum diketahui meskipun hipertensi merupakan penyakit yang paling sering muncul bersama DM tipe 2 .

Penderita DM tipe 2 memiliki kondisi yang disebut dengan resistensi insulin dimana insulin yang tidak digunakan untuk merombak glukosa dapat mengakibatkan peningkatan retensi natrium di ginjal dan meningkatkan aktivitas sistem syaraf simpatik. Retensi natrium dan meningkatnya aktivitas sistem syaraf simpatik merupakan dua hal yang berpengaruh terhadap meningkatnya tekanan darah. ${ }^{12}$ Hipertensi pada DM tipe 2 juga disebabkan hiperglikemia yang meningkatkan angiostensin II dan menyebabkan terjadinya hipertensi. ${ }^{13}$ Kerusakan lapisan endotel arteri akibat tingginya kadar glukosa dalam darah, metabolit glukosa, atau tingginya kadar asam lemak dalam darah menyebabkan permeabilitas sel endotel meningkat sehingga molekul yang mengandung lemak masuk ke arteri. Kerusakan sel-sel endotel akan mencetuskan reaksi imun dan inflamasi sehingga akhirnya terjadi pengendapan trombosit, makrofag, dan jaringan fibrosis serta proliferasi sel otot polos pembuluh darah yang merupakan awal terjadinya lesi aterosklerosis dalam pembuluh darah sehingga memicu peningkatan tekanan darah. ${ }^{14}$

Faktor risiko hipertensi pada DM tipe 2 terdiri dari faktor yang tidak dapat diubah dan dapat diubah. Faktor tidak dapat diubah yaitu umur, jenis kelamin, genetik dan lama menderita DM. ${ }^{15-18}$ Sedangkan faktor yang dapat diubah meliputi kebiasaan merokok ${ }^{19}$, aktivitas fisik, kebiasaan makan asin ${ }^{15}$, kebiasaan minum kopi ${ }^{20}$, kepatuhan diet 
$\mathrm{DM}^{21}$, kepatuhan minum obat $\mathrm{DM}^{22}$, dan lama waktu tidur. ${ }^{23}$

Penelitian dan data terkait faktor risiko kejadian hipertensi pada penderita DM tipe 2 masih sangat jarang, sedangkan memahami faktor risiko hipertensi pada penderita DM tipe 2 sangat diperlukan dalam memantau peningkatan kasus dan pencegahan terjadinya komplikasi mikro dan makrovaskuler. Maka sangat perlu untuk mengetahui pengaruh dan keterkaitan antara usia, jenis kelamin, lama menderita DM, kepatuhan diet DM, kepatuhan minum obat DM, riwayat hipertensi pada keluarga, kebiasaan merokok, aktivitas fisik, kebiasaan makan asin, kebiasaan minum kopi, dan lama waktu tidur terhadap terjadinya hipertensi pada penderita DM tipe 2. Oleh karena itu peneliti bermaksud untuk menganalisis faktor-faktor apa sajakah yang berpengaruh terhadap terjadinya hipertensi pada penderita DM tipe 2 di wilayah Puskesmas di Kabupaten Pati.

\section{Metode}

Jenis penelitian yang dilakukan adalah studi observasional analitik dengan desain studi case control. Variabel terikat pada penelitian ini adalah kejadian hipertensi pada penderita DM tipe 2 . Variabel bebas dalam penelitian ini usia $\geq 45$ tahun, jenis kelamin laki-laki, lama menderita DM, kepatuhan diet DM, kepatuhan minum obat DM, riwayat hipertensi pada keluarga, kebiasaan merokok, aktivitas fisik, kebiasaan makan asin, kebiasaan minum kopi, dan lama waktu tidur.

Populasi rujukan adalah seluruh penduduk dengan diagnosis DM tipe 2 . Populasi studi adalah penduduk dengan diagnosis DM tipe 2 yang menderita hipertensi di wilayah Puskesmas Kabupaten Pati. Populasi studi adalah penduduk dengan diagnosis DM tipe 2 yang menderita hipertensi yang ada di wilayah Puskesmas di Kabupaten Pati. Sampel kasus adalah penduduk yang berkunjung ke Puskesmas di Kabupaten Pati selama tahun 2014 dengan diagnosis DM tipe 2 dan menderita hipertensi. Sampel kontrol adalah penduduk yang berkunjung ke Puskesmas di Kabupaten Pati selama tahun 2014 dengan diagnosis DM Tipe 2 dan tidak menderita hipertensi.

Pengambilan sampel secara Multistage sampling yaitu pengambilan sampel yang dilakukan secara bertahap lebih dari satu kali untuk mendapatkan calon responden yang diinginkan dengan probabilitas yang sama. Tahap pertama adalah penentuan lokasi Puskesmas yang dilakukan dengan pertimbangan karakteristik geografi yang membagi 29 Puskesmas di Kabupaten Pati ke dalam 4 wilayah geografis, kemudian dipilih secara acak 1 Puskesmas pada setiap kelompok. Puskesmas yang dipilih sebagai lokasi penelitian adalah Puskesmas Gembong (mewakili karakteristik wilayah lereng gunung Muria), Puskesmas Trangkil (mewakili karakteristik wilayah dataran rendah dan pantai), Puskesmas Kayen (mewakili karakteristik wilayah pegunungan Kapur), dan Puskesmas Pati I (mewakili karakteristik wilayah perkotaan).

Tahap kedua adalah penentuan sampel/responden penelitian. Setiap Puskesmas yang terpilih sebagai lokasi penelitian, secara simple random sampling diambil 15 responden kasus dan 15 responden kontrol sehingga diperoleh 60 responden kasus dan 60 responden kontrol sesuai perhitungan besar sampel minimal.

Kriteria inklusi kasus adalah penderita DM Tipe 2 yang menderita hipertensi berdasarkan diagnosis oleh dokter Puskesmas dalam kurun waktu Januari-Desember 2014 dan bersedia menjadi responden dengan informed consent. Kriteria eksklusi kasus adalah tidak bertempat tinggal di wilayah 
Puskesmas Kabupaten Pati dan terlebih dahulu menderita hipertensi sebelum terdiagnosa DM Tipe 2. Kriteria inklusi kontrol adalah penderita DM tipe 2 yang tidak menderita hipertensi berdasarkan diagnosis oleh dokter Puskesmas dalam selama kurun waktu Januari - Desember 2014 dan bersedia menjadi responden dengan informed consent. Kriteria ekslusi kontrol yaitu tidak bertempat tinggal di wilayah Puskesmas Kabupaten Pati.

Instrumen penelitian yang digunakan adalah kuesioner. Pengolahan dan analisa data dilakukan dengan program SPSS meliputi analisis univariat, bivariat dengan uji chi square dan multivariat dengan regresi logistik ganda.

\section{Hasil}

Jumlah responden penelitian sebanyak 114 orang, terdiri 57 orang penderita DM tipe 2 dengan hipertensi sebagai kasus dan 57 orang penderita DM tipe 2 tanpa hipertensi sebagai kontrol.
Hasil analisis bivariat menunjukkan bahwa faktor yang berpengaruh terhadap terjadinya hipertensi pada penderita DM tipe 2 adalah usia $\geq 45$ tahun $(\mathrm{OR}=10,5$; $\mathrm{p}=0,020)$,lama $\geq 5 \operatorname{tahun}(\mathrm{OR}=4,1 ; \mathrm{p}=0,001)$, kepatuhan diet $\mathrm{DM} \quad(\mathrm{OR}=3 ; \mathrm{p}=0,011)$, kepatuhan minum obat $\mathrm{DM} \quad(\mathrm{OR}=3,6$; $\mathrm{p}=0,02)$ dan aktivitas fisik kurang $(\mathrm{OR}=4,8$; $\mathrm{p}=0,001)$ (Tabel 1).

Analisis multivariat (Tabel 2) menunjukkan bahwa variabel yang berpengaruh terhadap terjadinya hipertensi pada penderita DM tipe 2 adalah aktivitas fisik kurang $(\mathrm{OR}=6,4 ; \quad \mathrm{p}=0,001)$, lama menderita $\mathrm{DM} \geq 5$ tahun $(\mathrm{OR}=5,4 ; \mathrm{p}=$ 0,001) dan kepatuhan minum obat DM $(\mathrm{OR}=3.6 ; \mathrm{p}=0,012)$. Hasil perhitungan persamaan MLR menunjukkan bahwa seorang penderita DM dengan aktivitas fisik kurang yaitu kebiasaan olah raga/pekerjaan berat kurang dari 3 kali seminggu selama 30 menit, lama menderita $\mathrm{DM} \geq 5$ tahun, dan tidak patuh minum obat DM memiliki probabilitas atau risiko terjadi hipertensi sebesar $88,63 \%$.

Tabel 1. Rangkuman hasil analisis bivariat variabel bebas terhadap terjadinya hipertensi pada penderita DM tipe 2

\begin{tabular}{clcccc}
\hline \multirow{2}{*}{ No } & \multicolumn{1}{c}{ Variabel } & \multirow{2}{*}{ Nilai $\mathrm{p}$} & OR & \multicolumn{2}{c}{ 95 \% CI } \\
\cline { 5 - 6 } & & 0,020 & 10,5 & 1,28 & 85,88 \\
1. & Usia $\geq 45$ thn & 0,828 & 0,827 & 0,35 & 1,94 \\
2. & Jenis kelamin laki-laki & 0,001 & 4,1 & 1,83 & 9,48 \\
3. & Lama DM $\geq$ 5 tahun & 0,011 & 3 & 1,36 & 6,83 \\
4. & Kepatuhan diet DM & 0,002 & 3,6 & 1,65 & 8,13 \\
5. & Kepatuhan minum obat DM & 0,446 & 1,5 & 0,65 & 3,55 \\
6. & Riwayat hipertensi & 1,000 & 1,1 & 0,44 & 2,9 \\
7. & Kebiasaan merokok & 0,001 & 4,8 & 1,98 & 11,59 \\
8. & Aktivitas fisik kurang & 0,699 & 1,3 & 0,58 & 2,67 \\
9. & Kebiasaan makan asin & 0,629 & 1,4 & 0,55 & 3,7 \\
10. & Kebiasaan minum kopi & 0,609 & 1,3 & 0,61 & 2,83 \\
11. & Lama waktu tidur & & & & \\
\hline
\end{tabular}


Tabel 2. Hasil uji multiple logistic regresion faktor risiko yang berpengaruh terhadap terjadinya hipertensi pada DM tipe 2

\begin{tabular}{llcccl}
\hline No & \multicolumn{1}{c}{ Variabel } & B & Nilai p & OR & 95 \% CI \\
\hline 1. & Kepatuhan diet DM & 0,683 & 0,211 & 1,9 & $0,689-5,77$ \\
2. & Kepatuhan minum obat DM (-) & 1,283 & 0,012 & 3,6 & $1,32-9,83$ \\
3. & Aktivitas fisik kurang & 1,858 & 0,001 & 6,4 & $2,18-18,77$ \\
4. & Usia $\geq 45$ tahun & 2,057 & 0,078 & 7,8 & $0,790-77,11$ \\
5. & Lama DM $\geq 5$ tahun & 1,684 & 0,001 & 5,4 & $1,97-14,70$ \\
\hline & Constant & $-2,771$ & & & \\
\hline
\end{tabular}

\section{Pembahasan}

Berdasarkan analisis bivariat (Tabel 1) dan multivariat (Tabel 2) menyatakan bahwa individu yang memiliki aktivitas fisik kurang dari 3 kali seminggu selama minimal 30 menit memiliki risiko 6,4 kali mengalami hipertensi dibandingkan dengan individu yang memiliki aktivitas fisik cukup ( $\mathrm{p}=0,001 ; 95 \% \mathrm{CI}=2,18$ 18,77). Hasil ini sesuai dengan penelitian Sugiharto dimana orang yang tidak biasa melakukan aktivitas fisik mempunyai risiko menderita hipertensi sebesar 4,73 $(\mathrm{p}=0,001 ; 95 \% \mathrm{CI}=1,03-2,58) .{ }^{15}$

Orang yang tidak aktif melakukan kegiatan fisik cenderung mempunyai frekuensi denyut jantung lebih tinggi sebab mengakibatkan otot jantung bekerja lebih keras pada setiap kontraksi. Semakin keras usaha otot jantung memompa darah, semakin besar pula tekanan yang dibebankan pada dinding arteri. Hal ini menyebabkan peningkatan tahanan perifer sehingga menaikkan tekanan darah. ${ }^{15}$ Aktivitas fisik yang teratur pada penderita DM tipe 2 secara konsisten terbukti efektif menurunkan tekanan darah, menurunkan berat badan terutama jika dikombinasikan dengan diet kalori yang terkontrol, mengurangi kadar VLDL, menurunkan LDL, dan meningkatkan HDL. ${ }^{24}$

Individu yang memiliki durasi menderita DM selama $\geq 5$ tahun memiliki risiko 33,9 kali untuk mengalami hipertensi dibandingkan dengan individu yang memiliki durasi menderita DM <5 tahun $(\mathrm{p}=0,001 ; 95 \% \mathrm{CI}=4,19-274,84)$. Hasil ini sejalan dengan penelitian Fukui ${ }^{18}$ yang menyatakan ketika seseorang terlebih dahulu mengalami diabetes, maka hazard ratio untuk terjadi hipertensi pada tahun ke 5 adalah sebesar 2,359 $(95 \% \mathrm{CI}=1,700$ 3,724; $\mathrm{p}<0,0001)$. Lama menderita DM dapat menyebabkan terjadinya komplikasi. Pada DM terjadi paparan hiperglikemia kronik yang menyebabkan terjadinya komplikasi baik mikrovaskuler maupun makrovaskuler. $^{25}$

Kadar gula dalam darah yang terusmenerus tinggi dapat merusak pembuluh darah melalui berbagai mekanisme pada tingkat jaringan, sel dan biokimia menimbulkan stres oksidatif, aktivasi protein kinase $\mathrm{C}(\mathrm{PKC})$, reseptor advanced glycated end product (RAGE), sehingga menyebabkan vasokonstriksi, aktivasi respon peradangan dan trombosis. ${ }^{26}$ Kerusakan sel-sel endotel akibat hiperglikemi mencetuskan reaksi imun dan inflamasi sehingga akhirnya terjadi pengendapan trombosit, makrofag, dan jaringan fibrosis serta proliferasi sel otot polos pembuluh darah yang merupakan awal terjadinya lesi aterosklerosis. Terjadinya aterosklerosis pada pembuluh darah dalam jangka panjang dapat memicu peningkatan tekanan darah. ${ }^{14}$

Analisis multivariat menunjukkan bahwa individu yang tidak patuh minum obat DM memiliki risiko 9,1 kali mengalami hipertensi dibandingkan 
dengan yang patuh minum obat $(\mathrm{p}=0,031$; 95\% CI=1,23-68,11). Penelitian diabetes yang tidak patuh minum obat hipoglikemik oral memiliki risiko 8,6 kali mengalami peningkatan kadar gula darah penyebab komplikasi $^{22}$.

Ketidakteraturan minum obat dapat menimbulkan komplikasi kronik lebih dini karena terjadi hiperglikemi kronis pada penderita DM. Hal ini akan menimbulkan aterosklerosis dan trombosis, serta peningkatan glikosilasi protein yang mempengaruhi integritas dinding pembuluh darah. Upaya penting untuk mencegah progresifitas komplikasi vaskular seperti tekanan darah adalah dengan mengendalian kadar glukosa. ${ }^{27}$

Variabel yang tidak terbukti berpengaruh terhadap terjadinya hipertensi pada penderita DM tipe 2 adalah usia $\geq 45$ tahun, jenis kelamin laki-laki, kepatuhan diet DM, riwayat hipertensi, kebiasaan merokok, kebiasaan makan asin, kebiasaan minum kopi, dan lama waktu tidur. Variabel usia $\geq 45$ tahun tidak terbukti sebagai faktor risiko disebabkan karena adanya pengaruh dari variabel lain yang lebih kuat dalam analisis multivariat. Jenis kelamin laki-laki tidak terbukti sebagai faktor risiko karena jenis kelamin pada seluruh subyek penelitian homogen, dimana jumlah responden perempuan 3 kali lebih banyak daripada responden lakilaki.

Kepatuhan diet DM tidak terbukti sebagai faktor risiko karena adanya pengaruh dari variabel lain yang lebih kuat saat dianalisis bersama-sama. Riwayat hipertensi pada keluarga tidak terbukti sebagai faktor risiko karena kesetaraan proporsi paparan pada kasus $(57,1 \%)$ dan kontrol (46,7\%). Selain itu dari 114 responden, hanya 87 orang yang dapat menjawab status riwayat hipertensi pada keluarga, sedangkan 27 orang lainnya menjawab tidak tahu. Kebiasaan merokok tidak terbukti sebagai faktor risiko karena adanya kesetaraan proporsi paparan pada kasus (19,3\%) dan kontrol (17,5\%). Merokok juga masih didominasi oleh lakilaki sedangkan $75,4 \%$ subyek penelitian ini adalah perempuan yang tidak merokok.

Kebiasaan makan asin tidak terbukti sebagai faktor risiko karena proporsi responden yang makan asin pada kasus $64,9 \%$ hampir setara dengan kontrol $59,6 \%$. Selain itu penelitian ini tidak memisahkan antara penggunaan natrium klorida (garam dapur) dengan penyedap rasa monosodium glutamate (MSG).

Kebiasaan minum kopi tidak terbukti sebagai faktor risiko karena minum kopi masih didominasi oleh laki-laki. Lama waktu tidur tidak terbukti sebagai faktor risiko karena proporsi paparan pada kasus $(40,4 \%)$ dan kontrol $(33,9 \%)$ yang tidak jauh berbeda sehingga menyebabkan tidak adanya pengaruh yang signifikan.

\section{Kesimpulan}

Faktor risiko yang terbukti berpengaruh terhadap terjadinya hipertensi pada penderita DM tipe 2 adalah aktivitas fisik yang kurang, lama menderita DM, dan kepatuhan minum obat DM. Sedangkan yang tidak terbukti berpengaruh adalah usia $\geq 45$ tahun, jenis kelamin laki-laki, kepatuhan diet DM, riwayat hipertensi, kebiasaan merokok, kebiasaan makan asin, kebiasaan minum kopi, dan lama waktu tidur.

\section{Ucapan Terimakasih}

Terimakasih kepada Kepala Dinas Kesehatan Kabupaten Pati dan staf yang telah memberikan izin, dukungan serta motivasi selama melakukan penelitian di wilayah kerjanya. 


\section{Daftar Pustaka}

1. Anonim. 2014. American Diabetes Association.Clinical Practice Recommendations Report of the Expert Commite on the Diagnosis and Classifications of Diabetes Mellitus. Diabetes Care. pp.81-90.

2. Guyton AC.1994.Fisiologi Manusia dan Mekanisme Penyakit.Jakarta:EGC Penerbit Buku Kedokteran.pp.734736.

3. Waspadji S.2010.Komplikasi Kronik Diabetes: Mekanisme Terjadinya, Diagnosis dan Strategi Pengelolaan. Buku Ajar Ilmu Penyakit Dalam. Aru Sudoyo, Bambang Setiyohadi, Idrus Alwi, Marcellus Simadibrata, dan Siti Setiati. Edisi V. Jakarta: Interna Publishing.pp.22-33.

4. American Diabetes Association. 2004. Hypertension Management in Adults with Diabetes (Position Statement). Diabetes Care.pp.65 -72.

5. Suyono S. 2007. Kecenderungan Peningkatan Jumlah Penyandang Diabetes Dan Patofisiologi Diabetes Melitus. Dalam: Sugondo S, Soewondo P, Subekti I, editor (penyunting). Penatalaksanaan Diabetes Melitus Terpadu. Jakarta:FK UI.pp.7-18.

6. Selim S, Abougalambou I, Abougalambo AS. 2013. A Study Evaluating Prevalence Of Hypertension and Risk Factors Affecting on Blood Pressure Control Among Type 2 Diabetes Patients Attending Teaching Hospital in Malaysia. Diabetes \& Metabolic Syndrome:ClinicalResearch \& Reviews.pp.83-86.

7. Beckman J, Creager MA, Libby P. 2002. Diabetes And Atherosclerosis Epidemiology Pathophysiology And Management. American Medical Association. JAMA. pp.70-81.
8. IDF Diabetes Atlas sixth edition. International Diabetes Federation. 2013. online version of IDF Diabetes Atlas: www.idf.org/diabetesatlas

9. Simonson DC. 1988. Etiology and Prevalence of Hypertension in Diabetic Patients. Diabetes care.pp.822-827.

10. Colosia AD, Palencia R, Khan S.2013.Prevalence of Hypertension And Obesity in Patients With Type 2 Diabetes Mellitus in Observational Studies: A Systematic Literature Review. Diabetes, Metabolic Syndrome and Obesity: Targets and Therapy.pp.327-338.

11. Badan Penelitian dan Pengembangan Kesehatan. 2013. Riset Kesehatan Dasar. Jakarta: Kementerian Kesehatan Republik Indonesia.

12. Sassen JJ, Carter, BL. Hypertension. 2005. Pharmacotherapy: A Phatophysiologic Approach. Editor: Joseph Dipiro, Robert Talbert, Gary Yee, Gary Matzke, Barbara Wells, dan Michael Posey. Edisi 8. New York : Appleton and Lange.pp.186-217.

13. Modesti A, Bertolozzi I, Gamberi T, et al. 2005. Hyperglycemia Activates JAK2 Signaling Pathway in Human Failing Myocytes Via Angiotensin II Mediated Oxidative Stress. Diabetes.pp.394-401.

14. Corwin EJ. 2009. Pankreas dan Diabetes Melitus. Dalam Elizabeth J. Corwin. editor: Buku Saku Patofisiologi. Edisi 3. Jakarta: EGC. pp. 621-627.

15. Sugiarto A. 2007. Faktor-faktor Risiko Hipertensi Grade II pada Masyarakat (Studi Kasus di Kabupaten Karanganyar). Tesis. Semarang : Program Studi Magister Epidemiologi Universitas Diponegoro. Available from: http://eprints.undip.ac.id/. 
16. Shapo L, Pomerleau J, McKee M. 2003. Epidemiology of Hypertension and Associated Cardiovascular Risk Factors in a Country in Transition. Albania: Journal Epidemiology Community Health.pp.734-739.

17. Tseng, $\mathrm{CH}$.2007. Effect of parental hypertension and/or parental diabetes on hypertension in Taiwanese diabetic patients. European Journal of Clinical Investigation.pp: 870-877.

18. Fukui M, et al. 2011. Risk factors for Development of Diabetes Mellitus, Hypertension and Dyslipidemia. Diabetes Research and Clinical Practice.pp.15-18.

19. Wei M, Mitchell BD, Haffner SM, et al.1996. Effects of Cigarette Smoking, Diabetes, High Cholesterol, and Hypertension on All-Cause Mortality and Cardiovascular Disease Mortality in Mexican Americans The San Antonio Heart Study. Am J Epidemiol.pp.1058-1065.

20. Uiterwaal C, Verschuren M, Bueno-de Mesquita B, et al. 2007. Coffee Intake and Incidence of Hypertension. Am J Clin Nutr.pp.718-723.

21. Tan SL, Juliana S, Sakinah H. 2011. Dietary Compliance and its Association with Glycemic Control among Poorly Controlled Type 2 Diabetic Outpatients in Hospital Universiti Sains Malaysia. Mal J Nuts.pp.287-299.
22. Sulistyaningsih W, Puspitawati T, Nugroho DK.2011. Hubungan Tingkat Kepatuhan Minum Obat Hipoglikemik Oral dengan Kadar Glukosa Darah pada Pasien Diabetes Melitus Tipe 2. Berita Kedokteran Masyarakat.pp.215221.

23. Buxton OM, Marcelli E. 2010. Short and Long Sleep Are Positively Associated With Obesity, Diabetes, Hypertension, And Cardiovascular Disease Among Adults In The United States. Social Science \& Medicine. pp.1027-1036.

24. Kokkinos PF, Giannelou A, Manolis A, Pittaras A. 2009. Physical Activity in the Prevention and Management of High Blood Pressure. Hellenic J Cardiol.pp.52-59.

25. Ludirdja JS, et al.2010.Rerata Durasi Penderita Diabetes Melitus Terkena Nefropati Diabetik Sejak Terdiagnosis Diabetes Melitus Pada Pasien Di Poliklinik Geriatri RSUP Sanglah. IPTEKMA.2(1).pp.1-4.

26. Feener EP, Dzau VJ. 2006. Pathogenesis of Cardiovascular Disease in Diabetes. In Kahn CR, Weir GC, King GL, Jacobson AM, Moses AC, Smith RJ,(eds). Joslin's Diabetes Mellitus, $14^{\text {th }}$ ed.

27. Darmono.2000. Patofisiologi Komplikasi Vaskular Diabetes Mellitus. M. Med. Indonesia;35(2) 